\title{
Application of the climate analogue concept in assessing the probable physiological and haematological responses of Friesian cattle to changing and variable climate in the Kenyan Highlands
}

\author{
J.C. Wangui ${ }^{1,2 \#}$, B.O. Bebe ${ }^{1}$, J.O. Ondiek ${ }^{1}$ \& S.O. Oseni ${ }^{3}$ \\ ${ }^{1}$ Department of Animal Sciences, Egerton University, P.O. Box 536, Egerton, Kenya \\ ${ }^{2}$ Department of Livestock Production, Wajir County, P.O. Box 545, Wajir, Kenya \\ ${ }^{3}$ Department of Animal Sciences, Obafemi Awolowo University, lle Ife, Nigeria
}

(Received 30 October 2017; Accepted 23 February 2018; First published online 4 July 2018)

Copyright resides with the authors in terms of the Creative Commons Attribution 4.0 South African Licence.
See: http://creativecommons.org/licenses/by/4.0/za

\begin{abstract}
Friesian cattle are considered the most sensitive to climate change-induced thermal stress and remain the major dairy breed in Kenya. This study applied the climate analogue concept to predict probable physiological and haematological responses of Friesian cattle in the 2050s to understand their adaptability to a changing and variable climate. Njoro in the Kenya Rift Valley Highlands was used as the reference site and its 2050s climate analogue site was identified in Shawa, based on criteria of a similarity index of 0.8-0.9. Results suggest that Njoro in the 2050s will likely experience increasing temperatures, but changes in rainfall are uncertain. The increasing temperatures will probably be accompanied by mild thermal stress for Friesian cattle during the dry seasons or drought. The thermal humidity index differed between times of day, but not between the analogue sites. Except for rectal temperatures, the physiological and haematological responses differed between the analogue sites, but were within the normal ranges. It is concluded that Friesian cattle in Njoro in the 2050s will probably experience mild thermal stress in the afternoons during the dry seasons, expressed by slight increases in physiological and haematological responses, but will probably remain within the normal margins.
\end{abstract}

Keywords: Dairy cattle, haematimetric, Njoro, Rongai, thermal humidity index

\# Corresponding author: jchege@kilimo.go.ke, prejaw@gmail.com

\section{Introduction}

High ambient temperature can be a limiting environmental factor to the productive utilization of exotic dairy cattle breeds and their crosses in the tropics. The high environmental temperatures expressed as thermal stress cause reduced feed intake and impaired metabolism, which consequently translate to low milk yield, and suboptimal fertility and health performances (Abdelatif \& Alameen, 2012; Rana et al., 2014). As homeotherms, dairy cattle have thermal comfort zones, within which they maintain homeothermy and above which they become exposed to thermal stress. Ambient temperatures between $16{ }^{\circ} \mathrm{C}$ and $26{ }^{\circ} \mathrm{C}$ correspond to the thermal comfort zone of dairy cattle, and heat loss mechanisms (radiation, convection, and conduction) are sufficient for thermal regulation (Abdelatif \& Alameen, 2012; Kucevic et al., 2013; Das et al., 2016).

When exposed to thermal stress, dairy cows adjust their physiological responses to increase heat dissipation to the environment, subsequently altering their haematological profiles. Physiological and haematological variations are therefore useful measures of comfort and adaptability of dairy cattle to thermal stress (Ganaie et al., 2013; Das et al., 2016). Widely used measurable physiological changes in cattle include skin and rectal temperatures, sweating, respiration and pulse rates (Farooq et al., 2010; Ganaie et al., 2013; Jian, Ke \& Cheng, 2015), while haematological changes include packed cell volume (PCV), blood cell counts and haematimetric parameters measured by the mean corpuscular volume (MCV) and mean corpuscular haemoglobin (MCH) (Ashour et al., 2011; Bhan et al., 2012; Roland et al., 2014; 
Onasanya et al., 2015). These responses are distinct and prolonged in temperate (Bos taurus) cattle breeds compared with tropical (B. indicus) cattle breeds, indicating poor adaptation to thermal stress by temperate breeds (Farooq et al., 2010). The traits that increase the vulnerability of temperate breeds to thermal stress have been well documented, and include stocky body, thick skin, dense hair and a few poorly developed sweat glands (Hansen, 2004; Chan et al., 2010; Jian et al., 2013). The superior thermal regulatory ability of tropical breeds such as the zebu compared with temperate breeds such as Friesian in the tropics is the result of a combination of reduced heat production and increased capacity of heat dissipation (Hansen, 2004).

The relationships between thermal regulation mechanisms and changes in ambient temperatures and relative humidity, known as the thermal humidity index (THI) have been studied (Schoen, 2005; Dikmen \& Hansen, 2009; Gaafar et al., 2011; Kucevic et al., 2013; Mazzullo et al., 2014). Several models have been developed, and their suitability analysed for use in assessing thermal stress levels in cattle (Schoen, 2005). The model that is mostly used, classifies thermal stress at four levels, namely thermal comfort zone, with THI values less than 72; mild at 72 to 78; high at 78 to 88; and above 88 as severe (Gaafar et al., 2011; Abdelatif \& Alameen, 2012; Das et al., 2016). With a THI of 72+, primary autonomic responses, which are presented by vasodilation of surface blood vessels, are initiated to increase blood flow to the heat exchange surfaces of the skin for evaporative heat dissipation through sweating (Gebremedhin et al., 2008). If sweating is overwhelmed, respiratory evaporative heat dissipation through elevated respiration rates begins and progresses to panting as THI exceeds 78 (Gomes et al., 2011; Jian et al., 2015).

Increase in respiration rates is commensurate with heightened pulse rates to supply more blood from the body core to heat dissipation surfaces. The elevated respiration rates increase ventilation, which affects the red blood cell (RBC) concentration and haematimetric parameters, while the sweating rate reduces electrolytes, hence blood volumes and induces changes in blood composition (Das et al., 2016). Indirectly, thermal stress through the hypothalamus, pituitary and adrenal system trigger the immune system, causing changes in leukocyte profiles (Chen et al., 2015). In prolonged and severe thermal stress, a reduced heart rate is typical as it is associated with reduced metabolic heat production (Farooq et al., 2010). Incidentally, continued exposure to thermal stress involuntarily causes behavioural changes such as shade seeking and reduction in feed intake.

The temperate cattle breed that is most utilized in Kenya's dairy industry is the Friesian, because of its high milk yield potential, unselective feeding behaviour in zero-grazing production units and large body weight, which translated to a high salvage value (Bebe et al., 2003; FAO, 2011). Like other temperate breeds that are poorly adapted to tropical conditions, the Friesian requires modifications in the management of the environment to ameliorate the effects of thermal stress (McManus et al., 2009). However, with climate change, the highland regions in which the breed is utilized are projected to experience increasing temperatures and variable rainfall (Huho \& Kosonei, 2013; USAID, 2010). Under such circumstances the comfort zone for the Friesian breed is likely to shift and expose the breed to adaptation difficulties related to thermal stress. Identifying the likely future climatic conditions for the regions in which Friesian cattle are utilized could be a milestone towards understanding the adaptation challenges the breed will experience.

The Consultative Group on International Agricultural Research's (CGIAR) Research Programme on Climate Change and Food Security (CCAFS) has developed a tool and online platform that help identify areas where climatic conditions today resemble the climate projected for a selected area (Ramirez-Villegas et al., 2011). The tool works by using data for climate and bioclimatic variables for a chosen reference site to predict future climatic scenarios using global climate models (GCM) and SRES (Special Report on Emission Scenarios) for a specified timescale (Ramirez-Villegas et al., 2011). The future climatic scenarios are then compared and mapped to areas (globally or locally) in which they exist currently to give the probable future analogue sites to the reference site (Ramirez-Villegas et al., 2011). Using the two climate analogue sites (reference site and future climate analogue sites), comparative studies can be carried out to assess the adaptation opportunities and challenges to be expected (Ramirez-Villegas et al., 2011).

This study applied the climate analogue concept to predict probable physiological and haematological changes for Friesian cattle in the 2050s when utilized in the Kenya Highlands with a climate similar to that of Njoro currently.

\section{Materials and Methods}

Njoro (Figure 1) in the Rift Valley Highlands of Kenya was the selected reference study area because it has a high population of dairy farms that utilize Friesian cattle (1-3 cows/farm) (Omondi \& Njehia, 2014). Njoro lies between latitude $00^{\circ} 19^{\prime} 00^{\prime \prime} \mathrm{S}$ and longitude $36^{\circ} 06^{\prime} 00^{\prime \prime} \mathrm{E}$ in Low Highlands (LH3) and Upper midlands (UM4) ecological zones with an altitude of $2168 \mathrm{~m}$ to $2800 \mathrm{~m}$ above sea level. 


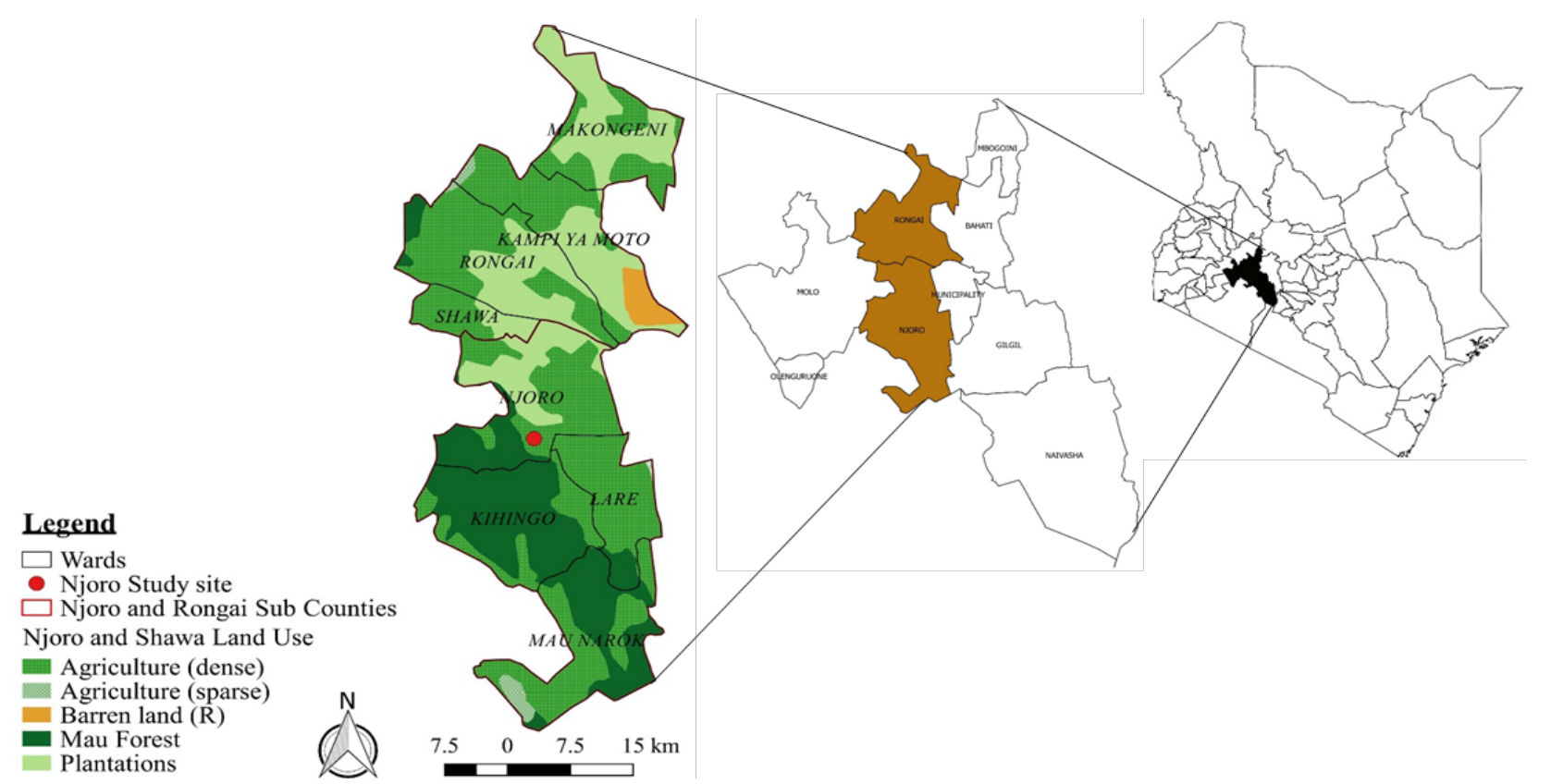

Figure 1 Study sites in Njoro and Shawa areas in Kenya

The CCAFS procedures and climate analogue tool online platform were applied with ensemble GCMs and SRES A1B to predict the analogue sites in the 2050s (Ramirez-Villegas et al., 2011). Climate variables of interest were mean monthly temperature and total monthly rainfall, which were run separately or combined. When combined, a weight of 0.5 was used for each variable to ensure equal contribution in calculating the analogues. In each run, applicable rotations (none, monthly mean temperature, monthly rainfall or both) were applied to check for seasonality effects. The default resolution of 30 arc seconds was maintained, and the minimum threshold of similarity index was set at 0.5. A nine-month growing period from March to November was assumed to be the replica to Njoro currently. Shawa area (Figure 1) in the Rift Valley was identified as the probable future climate analogue site to Njoro in 2050s, since it had the highest similarity index (0.8-0.9) and was consistent in all runs. Shawa lies between latitude $00^{\circ} 21^{\prime} 00^{\prime \prime}$ and longitude $36.8^{\circ} 08^{\prime} 59.99^{\prime \prime}$ at an altitude of 1650 to $1850 \mathrm{~m}$ above sea level in the Lower Midlands (LM3) and Upper Midlands (UM3) ecological zones.

Weather data during the study period and long-term climate data were obtained from Egerton University in Njoro, Gogar Farm in Shawa, weather stations and Kenya Meteorological Department.

A commercial dairy farm that keeps Friesian cattle breed was identified in each site to access animals to measure physiological and haematological indicators. Ngongongeri Farm was selected in Njoro and Gogar Farm in Shawa. Each farm had more than 200 mature Friesian cows of different physiological status. Thirty mature healthy and nongravid Friesian cows were selected from two age groups (young cows aged $4 \pm 1$ years and old cows aged $7 \pm 1$ years) in each farm. The age groups were used to assess their susceptibility to thermal stress. Cows in both farms were exposed directly to climatic stress in semi-intensive management practices. They were allowed to graze freely during the day and supplemented with total mixed ration in the morning and evening after milking. The cows in Gogar farm had ad libitum access to water, while those in Ngongongeri had timed watering in the morning, noon and evening.

The study was carried out in March 2016 in the hot season. The physiological parameters were taken twice a day (07:00 and 14:00) for four days, while blood samples were taken only on the last day. Physiological response variables were rectal temperature (RT), respiratory rate (RR), heart rate (HR) and sweating rate (SR). Rectal temperature was measured with a digital thermometer placed against the rectal walls, and readings were taken after the thermometer completion beep. Heart rate and RR were determined using a clinical stethoscope for one minute each. Sweating rate was measured using a technique described by Schleger \& Tuner (1995) and adapted by McManus et al. (2009). Three discs of about $0.5 \mathrm{~cm}^{2}$, cut from Whatman \#1 filter paper soaked in 10\% aqueous solution cobalt chloride and dried, were placed on a shaved area of about $5 \mathrm{~cm}^{2}$ on the lumbar vertebra. The average time taken for the discs to change colour from blue to pink was observed using a stopwatch. Sweating rate was then calculated using Schleger \& 
Tuner's (1995) equation SR $=384466.901 / \mathrm{t}\left(\mathrm{g} \mathrm{m}^{-2} \mathrm{~h}^{-1}\right)$, with $\mathbf{t}$ being time in seconds taken by the disc to change colour (McManus et al., 2009).

To determine haematological parameters, about $10 \mathrm{~mL}$ of whole blood was collected through coccygeal venipuncture into vacutainer tubes with EDTA on the fourth day, when physiological parameters were measured. Samples were chilled and transported to the Biotechnology Research Centre of Kenya Agricultural and Livestock Research Organization (KALRO), within 24 hours for analysis. Automated blood analysis using Coulter haematological analyser ( $A C \cdot$ T diff Beckman Coulter ${ }^{\mathrm{TM}}$ ) was used to investigate hematological parameters, packed cell volume (PCV), blood cell counts (white blood cells (WBC), red blood cells (RBC) and platelets (PIt)), haemoglobin ( $\mathrm{Hb})$ concentration; and haematimetric parameters (mean corpuscular volume (MCV), mean corpuscular haemoglobin $(\mathrm{MCH})$ and mean corpuscular haemoglobin concentration (MCHC)). Manual differential leucocytes counts were used to determine leukocyte types (lymphocytes, monocytes, eosinophils, and basophils) in percentages from a thin Wright's stain smear under optical microscope targeting fields of 100 cells.

Analysis of variance with the general linear model (GLM) procedures of SAS (2008) was used to determine the mean differences in climate variables (monthly total rainfall and mean temperatures), THI, physiological response variables (RR, RT, HR, and SR) and haematological variables (BCV, BCC and haematimetric parameters) between the climate analogue sites, by fitting the model:

$$
Y_{i j k}=S_{i}+T_{j}+E_{i j k}
$$

Where: $Y_{\mathrm{ijk}}=$ climate variables, $\mathrm{THI}$, physiological and hematological response variables

$\mathrm{S}_{\mathrm{i}}=$ fixed effect of sites

$\mathrm{T}_{\mathrm{j}}=$ time of day

$E_{i j k}=$ random error component associated with $Y_{i j k}$

THI was determined using the model:

Where: $T_{a}=$ average ambient temperatures

$$
T H I=(1.8) T_{a}-(1-R H)\left(T_{a}-14.3\right)+32
$$

$\mathrm{RH}=$ average relative humidity as a fraction

The THI indices were classified, namley THI less than 72 indicated Friesian cattle were within the thermal comfort zone; $72 \leq \mathrm{THI}<78$ in mild thermal stress;, $78 \leq \mathrm{THI}<89$ in severe thermal stress; $89 \leq \mathrm{THI}$ $<98$ in very severe thermal stress: and $98<$ in danger the zone (Gaafar et al., 2011; Abdelatif \& Alameen, 2012; Musari et al., 2014; Das et al., 2016).

Regression analysis for climate variables against time in years was used to obtain trend regression coefficients.

\section{Results}

Smallholder farms in Njoro used cut-and-carry zero-grazing and semi-zero-grazing production systems compared with Shawa, where more farms utilized semi-zero grazing and free grazing systems (Figure 2)

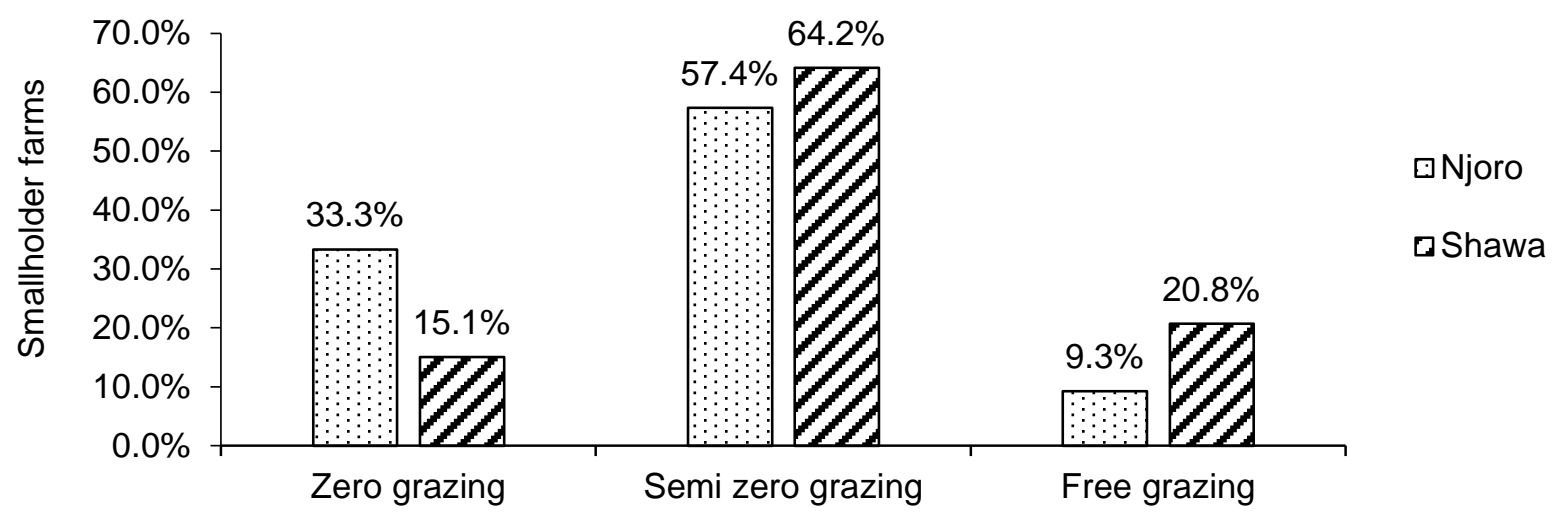

Dairy cattle production sytems

Figure 2 Dairy cattle production systems in Njoro and Shawa 
Using rainfall data for 50 years and temperature data for 30 years, the climatic variables differed between the climate analogue sites (Table 1). Njoro had higher monthly rainfall and the lowest temperatures relative to Shawa.

Table 1 Climatic variables for the climate analogue sites

\begin{tabular}{lcccc}
\hline $\begin{array}{l}\text { Analogue } \\
\text { sites }\end{array}$ & $\begin{array}{c}\text { Monthly total } \\
\text { rainfall }(\mathrm{mm})\end{array}$ & $\begin{array}{c}\text { Monthly mean } \\
\text { temperatures }\left({ }^{\circ} \mathrm{C}\right)\end{array}$ & $\begin{array}{c}\text { Monthly minimum } \\
\text { temperatures }\left({ }^{\circ} \mathrm{C}\right)\end{array}$ & $\begin{array}{c}\text { Monthly maximum } \\
\text { temperatures }\left({ }^{\circ} \mathrm{C}\right)\end{array}$ \\
\hline & & & & \\
Njoro & $86.3 \pm 2.14^{\mathrm{a}}$ & $16 \pm 0.12^{\mathrm{a}}$ & $10.2 \pm 0.16^{\mathrm{a}}$ & $23.3 \pm 0.20^{\mathrm{a}}$ \\
Shawa & $80.8 \pm 2.11^{\mathrm{b}}$ & $18.5 \pm 0.13^{\mathrm{b}}$ & $11.5 \pm 0.17^{\mathrm{b}}$ & $25.5 \pm 0.20^{\mathrm{b}}$
\end{tabular}

${ }^{\mathrm{ab}}$ Means with different letter superscripts within a column differ at $P<0.05$

Annual rainfall trends from 1964 to 2013 (Figure 3) showed a higher increase in Njoro $\left(3.30 \mathrm{~mm}, \mathrm{R}^{2}=\right.$ $0.044)$ compared with Shawa $\left(1.00 \mathrm{~mm}, \mathrm{R}^{2}=0.005\right)$. The increase was greatest in the October-NovemberDecember short rain season (Figure 4) with Njoro $\left(2.03 \mathrm{~mm}, \mathrm{R}^{2}=0.099\right)$ having a higher increase than Shawa $\left(0.95 \mathrm{~mm}, \mathrm{R}^{2}=0.021\right)$. Unlike Shawa, which had a weak increasing trend $\left(0.04 \mathrm{~mm}, \mathrm{R}^{2}=0.000\right)$, Njoro showed a declining trend for March-April-May season rainfall $\left(-0.29 \mathrm{~mm}, \mathrm{R}^{2}=0.001\right)$ (Figure 5).

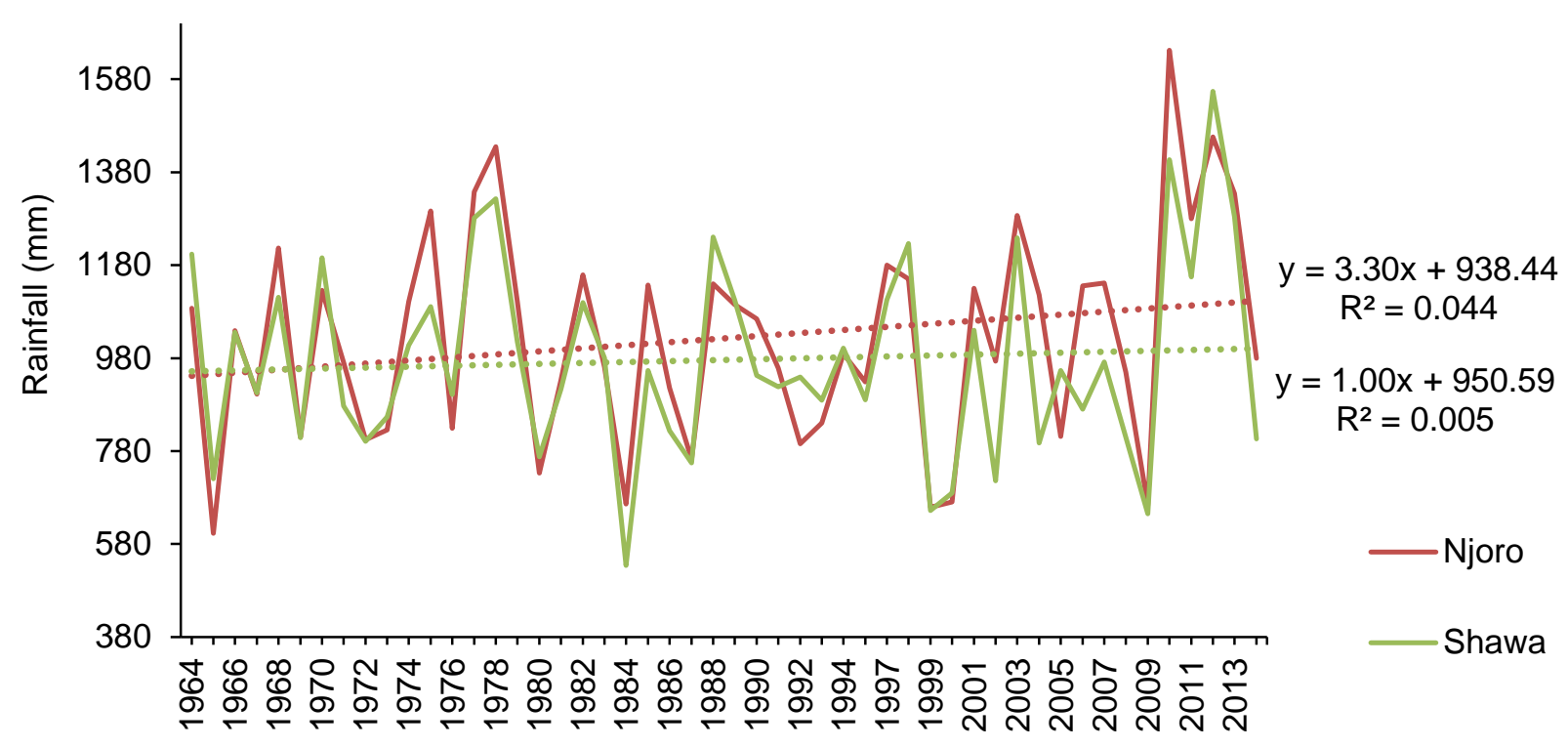

Time (Years)

Figure 3 Total annual rainfall trend for Njoro and Shawa

Temperature trends for Njoro and Shawa agreed with model predictions (Table 1 ) of increasing temperatures (Figure 6). Shawa $\left(0.08{ }^{\circ} \mathrm{C}, \mathrm{R}^{2}=0.806\right.$ ) showed a higher rate of increase for mean annual minimum temperature compared with Njoro $\left(0.02 \mathrm{O}^{\circ} \mathrm{C}, \mathrm{R}^{2}=0.294\right)$. On the other hand, Njoro $\left(0.03{ }^{\circ} \mathrm{C}, \mathrm{R}^{2}=\right.$ $0.301)$ had a higher increase in mean annual maximum temperature compared with Shawa $\left(0.02{ }^{\circ} \mathrm{C}, \mathrm{R}^{2}=\right.$ 0.070). This resulted in a higher rate of increase in mean annual temperature in Shawa $\left(0.05^{\circ} \mathrm{C}, \mathrm{R}^{2}=0.561\right)$ than in Njoro $\left(0.03^{\circ} \mathrm{C}, \mathrm{R}^{2}=0.514\right)$.

The daily THI during the study period differed $(P=0.0001)$ only between times of the day $(07: 00$ and 14:00), being higher in the afternoons (Table 2) in both sites, but did not differ between sites. 


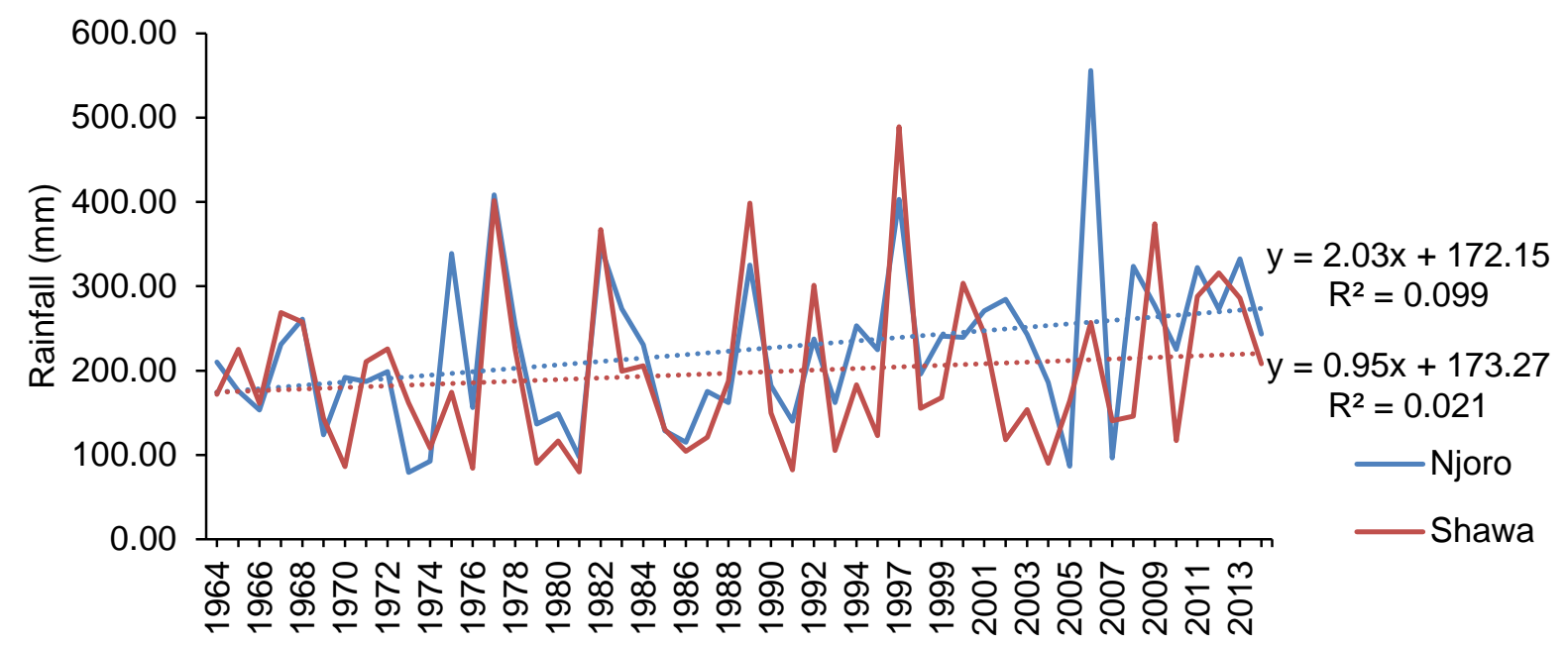

Time (Years)

Figure 4 October, November and December seasonal total rainfall trend for Njoro and Shawa

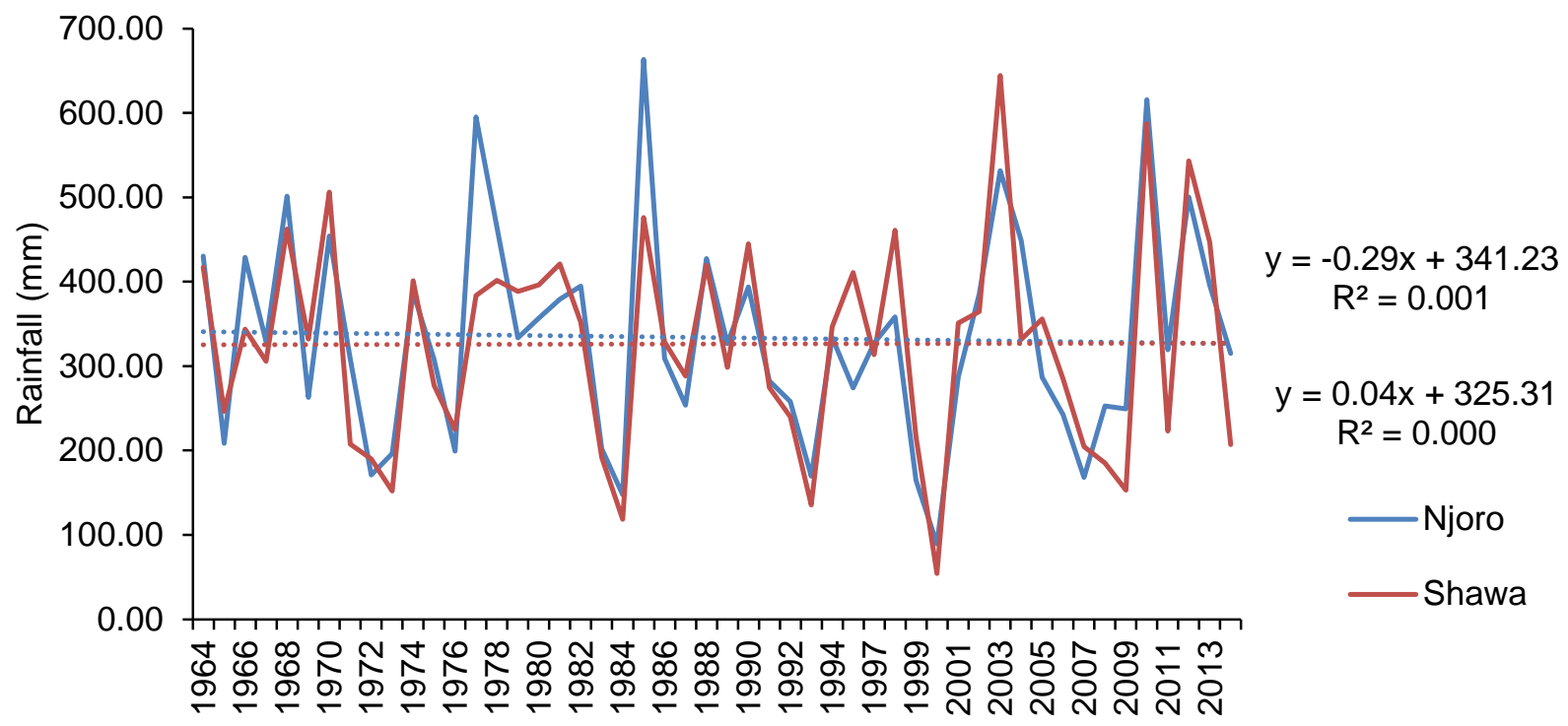

Time (Years)

Figure 5 March, April and May total rainfall trend for Njoro and Shawa 


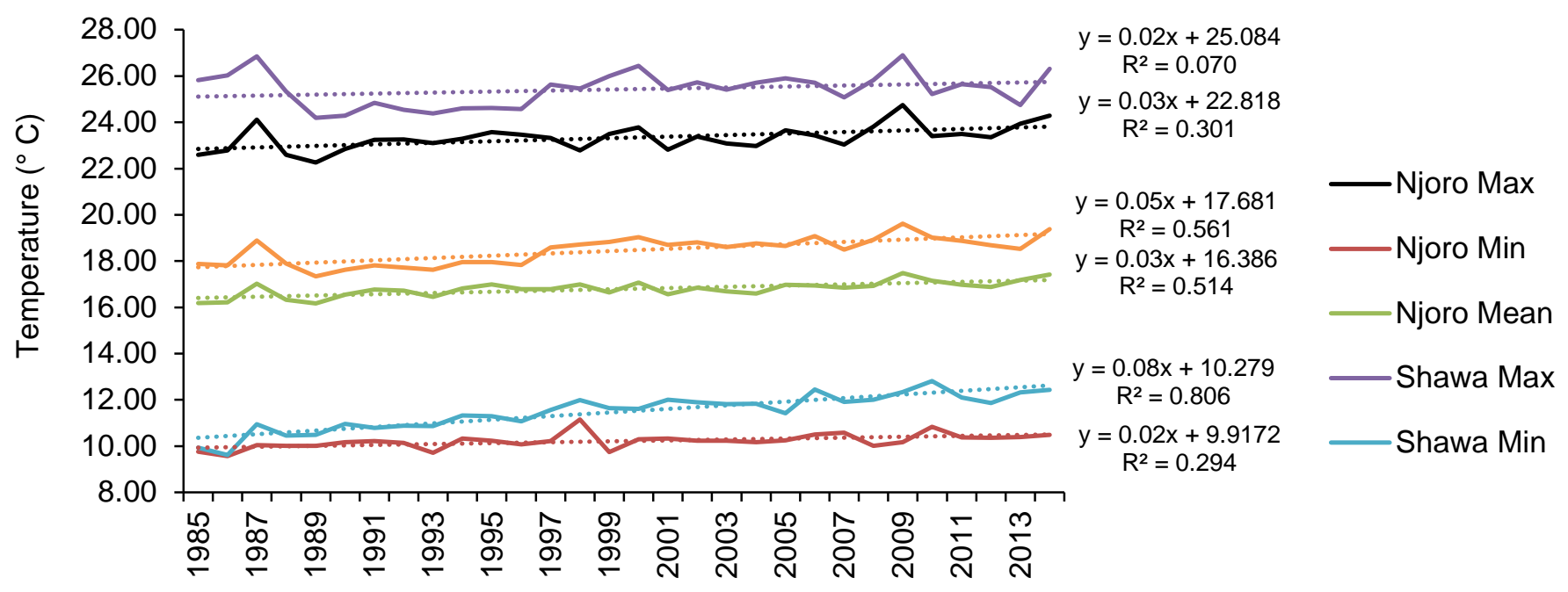

Time (Years)

Figure 6 Maximum, minimum and mean temperatures for Njoro and Shawa

Table 2 Thermal conditions for four days during the observation study in Njoro and Shawa

\begin{tabular}{|c|c|c|c|}
\hline \multirow{2}{*}{ Climate variables } & \multirow{2}{*}{$\begin{array}{c}\text { Climate analogue } \\
\text { sites }\end{array}$} & \multicolumn{2}{|c|}{ Time of the day } \\
\hline & & 07:00 & 14:00 \\
\hline \multirow{2}{*}{ Wet bulb temperatures $\left({ }^{\circ} \mathrm{C}\right)$} & Njoro & $14.8 \pm 0.57$ & $15.7 \pm 0.45$ \\
\hline & Shawa & $12.7 \pm 1.64$ & $17.1 \pm 1.16$ \\
\hline \multirow{2}{*}{ Dry bulb temperatures $\left({ }^{\circ} \mathrm{C}\right)$} & Njoro & $19.7 \pm 0.88$ & $26.6 \pm 1.43$ \\
\hline & Shawa & $19.0 \pm 1.38$ & $28.7 \pm 1.81$ \\
\hline \multirow{2}{*}{ Mean minimum temperature $\left({ }^{\circ} \mathrm{C}\right)$} & Njoro & $11.8^{\mathrm{a}} \pm 0.52$ & $18.3^{\mathrm{a}} \pm 0.70$ \\
\hline & Shawa & $13.0^{\mathrm{b}} \pm 1.40$ & $26.6^{b} \pm 0.80$ \\
\hline \multirow{2}{*}{ Mean maximum temperature $\left({ }^{\circ} \mathrm{C}\right)$} & Njoro & $27.3^{\mathrm{a}} \pm 1.17$ & $27.6^{a} \pm 0.26$ \\
\hline & Shawa & $19.0^{\mathrm{b}} \pm 1.40$ & $29.8^{b} \pm 0.59$ \\
\hline \multirow{2}{*}{ Mean temperature $\left({ }^{\circ} \mathrm{C}\right)$} & Njoro & $19.5^{\mathrm{a}} \pm 0.46$ & $23.0^{\mathrm{a}} \pm 0.43$ \\
\hline & Shawa & $16.0^{b} \pm 1.25$ & $28.2^{b} \pm 0.29$ \\
\hline \multirow{2}{*}{ Relative humidity (\%) } & Njoro & $56.2^{\mathrm{a}} \pm 9.60$ & $26.0^{\mathrm{a}} \pm 7.07$ \\
\hline & Shawa & $66.9^{b} \pm 9.03$ & $28.8^{a} \pm 10.86$ \\
\hline \multirow{2}{*}{ Thermal humidity index } & Njoro & $64.8 \pm 0.96$ & $66.9 \pm 0.50$ \\
\hline & Shawa & $60.2 \pm 1.81$ & $73.3 \pm 1.26$ \\
\hline
\end{tabular}

Of the physiological response indicators measured (Table 3 ) in Friesian cows in the two climate analogue sites, those in Shawa had higher heart rates $(P=0.0001)$, respiration rates $(P=0.0004)$ and sweating rates $(P=0.0009)$ in the afternoon, regardless of age group, but rectal temperatures did not differ $(P=0.0863)$. These observations are in harmony with the moderately high $\mathrm{THI}$ in the afternoon that was recorded for Shawa (Table 1). 
Table 3 Physiological response measures of Friesian cattle in the climate analogue sites for time of day and cattle age groups

\begin{tabular}{|c|c|c|c|c|c|}
\hline \multirow{2}{*}{$\begin{array}{l}\text { Physiological } \\
\text { measures }\end{array}$} & \multirow{2}{*}{$\begin{array}{c}\text { Climate analogue } \\
\text { sites }\end{array}$} & \multicolumn{2}{|c|}{ Time of the day } & \multicolumn{2}{|c|}{ Age group } \\
\hline & & 07:00 & $14: 00$ & $4 \pm 1$ years & $7 \pm 1$ years \\
\hline Rectal temperature & Njoro & $37.9 \pm 0.53$ & $38.9 \pm 0.32$ & $38.5 \pm 0.63$ & $38.3 \pm 0.68$ \\
\hline$\left({ }^{\circ} \mathrm{C}\right)$ & Shawa & $37.9 \pm 0.41$ & $38.8 \pm 0.43$ & $38.4 \pm 0.64$ & $38.2 \pm 0.55$ \\
\hline Sweating rate & Njoro & $227.3^{a} \pm 70.11$ & $408.2^{a} \pm 84.86$ & $284.4^{\mathrm{a}} \pm 124.19$ & $305.2^{\mathrm{a}} \pm 142.03$ \\
\hline$\left(g^{-2} h^{-1}\right)$ & Shawa & $183.1^{\mathrm{b}} \pm 60.64$ & $413.0^{b} \pm 107.89$ & $320.1^{b} \pm 129.96$ & $320.2^{b} \pm 130.81$ \\
\hline Respiration rate & Njoro & $32.2^{\mathrm{a}} \pm 5.67$ & $43.5^{\mathrm{a}} \pm 5.40$ & $38.4^{\mathrm{a}} \pm 8.52$ & $37.5^{\mathrm{a}} \pm 7.43$ \\
\hline (Breaths per minute) & Shawa & $28.4^{b} \pm 4.55$ & $51.9^{b} \pm 11.27$ & $40.3^{b} \pm 13.77$ & $39.9^{b} \pm 15.87$ \\
\hline Heart rate & Njoro & $58.3^{\mathrm{a}} \pm 6.01$ & $63.4^{\mathrm{a}} \pm 7.90$ & $60.3^{\mathrm{a}} \pm 7.71$ & $61.3^{\mathrm{a}} \pm 7.28$ \\
\hline (Beats per minute) & Shawa & $62.5^{\mathrm{b}} \pm 4.59$ & $73.1^{b} \pm 5.83$ & $68.2^{b} \pm 7.85$ & $67.1^{b} \pm 6.78$ \\
\hline
\end{tabular}

${ }^{\text {ab }}$ Means with different letter superscripts for each variable in a column differ $(P<0.05)$ between the analogue sites

For the haematological and haematimetric measures obtained in Friesian cows (Table 4), the differences between the two climate analogue sites were higher for Plt $(P=0.0087)$ and lower for PCV $(P=$ $0.0001), \mathrm{Hg}(P=0.0001), \mathrm{MCH}(P=0.0001), \operatorname{MCV}(P=0.0048)$, and MCHC $(P=0.0001)$ in Shawa, regardless of time of day and age group.

Table 4 Friesian cattle haematological measures between climate analogue sites for time of day and cattle age groups

\begin{tabular}{|c|c|c|c|c|c|}
\hline \multirow{2}{*}{$\begin{array}{l}\text { Haematological } \\
\text { Parameters }\end{array}$} & \multirow{2}{*}{$\begin{array}{l}\text { Climate analogue } \\
\text { sites }\end{array}$} & \multicolumn{2}{|c|}{ Time of the day } & \multicolumn{2}{|c|}{ Age group } \\
\hline & & 07:00 & $14: 00$ & $4 \pm 1$ years & $7 \pm 2$ years \\
\hline \multirow[t]{2}{*}{ PCV (\%) } & Njoro & $31.6^{\mathrm{a}} \pm 3.47$ & $32.0^{a} \pm 3.44$ & $30.9^{a} \pm 3.14$ & $32.5^{\mathrm{a}} \pm 3.54$ \\
\hline & Shawa & $26.6^{b} \pm 3.61$ & $26.7^{b} \pm 3.39$ & $26.2^{b} \pm 3.64$ & $27.5^{b} \pm 3.05$ \\
\hline \multirow[t]{2}{*}{$\mathrm{RBC}\left(\times 10^{6} \mathrm{cells} / \mu \mathrm{l}\right)$} & Njoro & $6.9 \pm 0.85$ & $6.7 \pm 0.68$ & $6.7 \pm 0.59$ & $6.9 \pm 0.88$ \\
\hline & Shawa & $7.0 \pm 0.69$ & $6.6 \pm 0.61$ & $6.7 \pm 0.76$ & $6.9 \pm 0.45$ \\
\hline \multirow[t]{2}{*}{ Plt $\left(x 10^{3}\right.$ cells $\left./ \mu \mathrm{l}\right)$} & Njoro & $213.4^{a} \pm 94.62$ & $198.3^{a} \pm 108.83$ & $191.2^{a} \pm 116.22$ & $216.5^{a} \pm 89.31$ \\
\hline & Shawa & $273.9^{b} \pm 134.42$ & $289.9^{b} \pm 149.70$ & $322.6^{b} \pm 134.16$ & $213.4^{b} \pm 128.92$ \\
\hline \multirow[t]{2}{*}{$\mathrm{Hg}(\mathrm{g} / \mathrm{dl})$} & Njoro & $10.9^{\mathrm{a}} \pm 1.36$ & $10.7^{\mathrm{a}} \pm 1.24$ & $10.6^{a} \pm 1.16$ & $11.0^{\mathrm{a}} \pm 1.37$ \\
\hline & Shawa & $8.9^{b} \pm 1.23$ & $8.6^{b} \pm 1.06$ & $8.6^{b} \pm 1.26$ & $9.0^{\mathrm{b}} \pm 0.90$ \\
\hline \multirow[t]{2}{*}{ MCV } & Njoro & $46.1^{a} \pm 3.77$ & $48.1^{a} \pm 3.20$ & $46.3^{a} \pm 3.54$ & $47.7^{a} \pm 3.58$ \\
\hline & Shawa & $38.2^{b} \pm 3.56$ & $40.3^{b} \pm 3.84$ & $39.0^{b} \pm 3.89$ & $39.8^{\mathrm{b}} \pm 3.71$ \\
\hline \multirow[t]{2}{*}{$\mathrm{MCH}$} & Njoro & $15.8^{\mathrm{a}} \pm 1.11$ & $16.1^{a} \pm 1.08$ & $15.8^{a} \pm 1.21$ & $16.1^{a} \pm 0.99$ \\
\hline & Shawa & $12.8^{\mathrm{b}} \pm 1.10$ & $13.0^{\mathrm{b}} \pm 1.14$ & $12.8^{\mathrm{b}} \pm 1.22$ & $13.0^{b} \pm 0.94$ \\
\hline \multirow[t]{2}{*}{$\mathrm{MCHC}$} & Njoro & $34.5^{\mathrm{a}} \pm 1.20$ & $33.5^{\mathrm{a}} \pm 0.72$ & $34.2^{\mathrm{a}} \pm 1.08$ & $33.8^{\mathrm{a}} \pm 1.12$ \\
\hline & Shawa & $33.1^{b} \pm 2.55$ & $32.3^{b} \pm 1.82$ & $33.0^{b} \pm 1.88$ & $32.2^{b} \pm 2.68$ \\
\hline
\end{tabular}

\footnotetext{
${ }^{\text {ab }}$ Means with different letter superscripts for each variable within a column differ $(P<0.05)$ between the analogue sites; PCV- Packed cell volume; RBC- Red blood cells; Plt- Platelets; Hg- Heamoglobin; MCV- Mean corpuscular volume; $\mathrm{MCH}$ - Mean corpuscular haemoglobin; MCHC- Mean corpuscular haemoglobin concentration
}

However, the haematological measures, including all leucocytes, were not different between the two climate site analogues, but in Shawa lymphocytes and neutrophils were the most numerous, while basophils 
were missing in the differential counts and the $\mathrm{N} / \mathrm{L}$ ratio was higher. These results are therefore not presented.

\section{Discussion}

Based on the temperature and rainfall patterns observed in Shawa, an increasing trend in temperature is likely, but the trend in rainfall is uncertain in Njoro in the 2050s. This is in agreement with other studies in the region, which show increasing trends in temperature (Washington \& Pearce, 2012; Daron, 2014; Musau et al., 2015; Gichangi et al., 2016;). However, studies in Kenya recorded mixed observations on projected trends for rainfall. McSweeney et al. (2010) reported a projection of $1 \%$ to $13 \%$ increase in Kenyan rainfall by the 2090s, Ngeno et al. (2014) observed a decreasing trend in rainfall for Rongai and Nandi South subcounties, while Washington \& Pearce (2012) and Gichangi (2016) indicated no clear trend for rainfall in Kenya. This uncertainty in rainfall trends can be attributed to heterogeneous topography, altitude, influence of sizable water bodies and atmospheric forces (Herrero et al., 2010; Owiti \& Zhu, 2012; Washington \& Pearce, 2012; Daron, 2014) resulting in greater interannual and diannual variability in rainfall amounts and distribution (King'uyu et al., 2009; Huho et al., 2012; Huho \& Kosonei, 2013; Musau et al., 2015).The THI in the two climate analogue sites reflected weather changes during the study period and revealed that Friesian cattle in Njoro were within thermal comfort zones, while those in Shawa experienced mild thermal stress in the afternoon. Using Shawa THI to construe thermal conditions for Njoro in the 2050s suggests that Friesian cattle will experience thermal comfort in the morning and mild thermal stress in the afternoon during dry seasons.

Rectal temperature did not turn out to be a differentiating indicator of thermal stress in Friesian cattle between the climate analogue sites, though it had a high correlation with body core temperatures (Gebremedhin et al., 2008; McManus et al., 2009; Ganaie et al., 2013). Friesian cows had rectal temperature within the normal ranges, suggesting thermal stress conditions in Njoro in the 2050s will not be notable from changes in rectal temperature. An above-normal rectal temperature range signifies overwhelmed thermal regulation mechanisms when $\mathrm{THI}$ exceeds 75 in dairy cattle (Kucevic et al., 2013). In the thermal comfort zone, the normal rectal temperature for dairy cattle can range between $38.4{ }^{\circ} \mathrm{C}$ and $39.1^{\circ} \mathrm{C}$, with an average of $38.6^{\circ} \mathrm{C}$ (Gantner et al., 2011; Kucevic et al., 2013).

Other physiological measures that are indicators of thermal stress, such as sweating rates and heart rates, were higher in Shawa relative to Njoro. Heightened sweating rate is the initial response for heat dissipation in cattle and varies among breeds. With the mild thermal stress of Friesian cattle suggested to be likely during dry seasons in the 2050s in Njoro, utilization of upgraded Friesians to pedigree level should be discouraged because of the likelihood of increased vulnerability to thermal stress. Sweating rate accounts for between $70 \%$ to $80 \%$ of evaporative heat loss, with the remainder being through the respiratory routes (Hansen, 2004). Friesian cattle experience limitations in their sweating rate, coupled with high metabolic rates to maintain the large body sizes and high production levels (McManus et al., 2009; Chan et al., 2010). There are breed differences in sweating efficiency, which suggests that alternative breeds for adaptability to thermal stress are possible. Bos indicus demonstrate more efficiency in sweating than $B$. taurus owing to a high number of well-developed sweat glands in the skin (Jian et al., 2013). As well as breed differences, skin colour affects sweating rate, with black having higher rates (Gebremedhin et al., 2008). The sweating rates observed in this study were higher than those reported by other researchers (Mc Manus et al., 2009; Gomes et al., 2011), but were within the observed margins (Gebremedhin et al., 2008; Chen et al., 2015) for the Friesian breed and its crosses in near similar climatic conditions.

Heat dissipation through the respiratory avenue is observed through heightened respiratory rates, which graduate into panting with an increase in thermal stress from mild to severe (Moran, 2012). Projections in this study show the likelihood of respiratory rates slightly above normal ranges in the afternoon (14:00), which corresponds to elevated ambient temperatures and THI (Ganaie et al., 2013). Changes in physiological responses to heat stress cause alterations in the haematological profile, making it a complement indicator of thermal stress. The study observed differences in haematological and haematimetric parameters except for RBC between Friesian cows in Njoro and those in Shawa. The RBC were highest for Friesian cows in Shawa at 07:00 and lowest at 14:00 compared with those in Njoro. Conversely, haemoglobin concentration and haematimetric parameters ( $\mathrm{MCV}, \mathrm{MCH}$, and $\mathrm{MCHC}$ ) were higher for Friesian cows in Njoro than for those in Shawa. The mild thermal stress observed in Shawa caused erythrolysis to reduce oxygen supply to the cells to suppress metabolic heat production (Das et al., 2016) and hence the observed changes in RBC, HC, and haematimetric parameters.

The leukograms for the study animals in both sites were within the normal ranges for cattle (Jackson \& Cockcroft, 2002; Roland et al., 2014), except for the WBC, which were overly exaggerated. The WBC anomaly resulted from erroneous configuration of correction values for WBC in the Coulter hematogical analyzer and did not affect other parameters. Nonetheless, PCV was lower in Friesian cows in Shawa 
relative to Njoro. The observed PCV for Friesian cows in Shawa could be attributed to haemoconcentration resulting from electrolytes loss under elevated evaporative heat loss through heightened sweating and respiration rates (McManus et al., 2009).

\section{Conclusion}

The study revealed that Friesian cattle currently in Njoro were within their thermal comfort zone, but would experience mild thermal stress in the afternoons during the dry seasons in the 2050s with the projected magnitude of climate change that is likely to occur. Their physiological and haematological responses will be elevated, but will probably remain within the normal margins.

\section{Acknowledgements}

The study received financial support from Egerton University Council Masters Scholarship and African Climate Change Fellowship (ACCFP III), Green Growth Masters Science Fellowship. The authors would also like to thank Obafemi Awolowo University, Animal Science Department for hosting the author, Kenya Meteorological Department, Egerton University and Gogar farm for providing valuable climatic data and Ngongongeri and Gogar farms for allowing the use of their animals and facilities during the study.

\section{Authors' Contributions}

JCW and BOO did the layout and the first draft of the manuscript. JOO and SOO edited the content of the manuscript.

\section{Conflict of Interest Declaration}

Authors declare no conflict of interest.

\section{References}

Abdelatif, A.M. \& Alameen, A.O., 2012. Influence of season and pregnancy on thermoregulation and haematological profile in crossbred dairy cows in tropical environment. Global Veterinaria 9(3), 334-340. http://doi.org/10.5829/idosi.gv.2012.9.3.65130

Ashour, G., Youssef, M.M. \& Shafie, M.M., 2011. Responses of hematology, blood metabolites, mineral ions and hormonal profile to heat stress for Egyptian buffalo-calves. Egyp. J. Agric. Res. 89(3), 1129-1140.

Bebe, B.O., Udo, H.M.J., Rowlands, G.J. \& Thorpe, W., 2003. Smallholder dairy systems in the Kenya highlands: Breed preferences and breeding practices. Livest. Prod. Sci. 82(2-3), 117-127. http://doi.org/10.1016/S03016226(03)00029-0

Bhan, C., Singh, S.V, Hooda, O.K., Upadhyay, R.C. \& Mangesh, V., 2012. Influence of temperature variability on physiological, hematological and bio- chemical profile of growing and adult Sahiwal cattle. J. Envir. Res. Devel. 7(2), 986-994.

Chan, E.K.F., Nagaraj, S.H. \& Reverter, A., 2010. The evolution of tropical adaptation: Comparing taurine and zebu cattle. Anim. Gen. 41, 467-477. http://doi.org/10.1111/j.1365-2052.2010.02053.x

Chen, Y., Arsenault, R., Napper, S. \& Griebel, P., 2015. Models and methods to investigate acute stress responses in cattle. Animals 5,1268-1295. http://doi.org/10.3390/ani5040411

Daron, D.J., 2014. Regional climate messages: East Africa. Scientific report from the CARIAA Adaptation at Scale in Semi-Arid Regions (ASSAR) Project. December 2014. Cape Town, South Africa. Accessed at http://www.uct.ac.za/

Das, R., Sailo, L., Verma, N., Bharti, P., Saikia, J. \& Kumar, R., 2016. Impact of heat stress on health and performance of dairy animals : A review. Vet. World 9(3), 260-268. http://doi.org/10.14202/vetworld.2016.260-268

Dikmen, S. \& Hansen, P.J., 2009. Is the temperature-humidity index the best indicator of heat stress in lactating dairy cows in a subtropical environment? J. Dairy Sci. 92, 109-116. http://doi.org/10.3168/jds.2008-1370

FAO., 2011. Dairy development in Kenya. FAO. Accessed at http://www.fao.org/docrep/013/al744e/al744e00.pdf

Farooq, U., Samad, H., Shehzad, F. \& Qayyum, A., 2010. Physiological responses of cattle to heat stress. World Appl. Sci. J. 8, 38-43. Accessed at http://www.idosi.org/wasj/wasj8(B\&GE)/8.pdf

Gaafar, H.M., Abu El-Hamd, M., El-Gendy, M., Bassiouni, M., Halawa, A. \& Shamiah, S., 2011. Effect of heat stress on performance of dairy Friesian cows. 2. Reproductive performance. Researcher 3(5), 94-100. Accessed at http://www.sciencepub.net/researcher

Ganaie, A.H., Shanker, G., Bumla, N.A., Ghasura, R.S., Mir, N.A., Sa, W. \& Gb, D., 2013. Biochemical and physiological changes during thermal stress in bovines. J. Vet. Sci. Technol. 4(1),1-6. http://doi.org/10.4172/21577579.1000126

Gantner, V., Mijić, P. \& Kuterovac, K., 2011. Temperature-humidity index values and their significance on the daily production of dairy cattle. Daily Production of Dairy Cattle 61(1),56-63.

Gebremedhin, K.G., Hillman, P.E., Lee, C.N., Collier, R.J., Willard, S.T., Arthington, J.D. \& Brandl, T.M.B., 2008. Sweating rates of dairy cows and beed heifers in hot conditions. Am. Soc. Agric. Biol. Eng. 51(6),2167-2178.

Gichangi, E.M., Wamuongo, J., Gatheru, M., Njiru, E.N., Mungube, E.O. \& Wambua, M.J., 2016. Assessment of climate variability and change in semi-arid eastern Kenya. Climatic Change 130(April), $287-297$. http://doi.org/10.1007/s10584-015-1341-2

Gomes, R., Sandro, A. \& Maia, C., 2011. Evaporative cooling and cutaneous surface temperature of Holstein cows in 
Resfriamento evaporativo e temperatura cutânea de vacas Holandesas em ambiente tropical. Revista Brasileira de Zootecnia 40(5),1143-1147.

Hansen, P.J., 2004. Physiological and cellular adaptations of zebu cattle to thermal stress. Anim. Reprod. Sci. 8283,349-360. http://doi.org/10.1016/j.anireprosci.2004.04.011

Herrero, M., Ringler, C., Steeg, J. Van De Koo, J. \& Notenbaert, A., 2010. Climate variability and climate change and their impacts on Kenya's agricultural sector. International Livestock Research Institute (ILRI), Nairobi. Kenya,1-56.

Huho, J.M. \& Kosonei, R.C., 2013. The opportunities and challenges for mitigating climate change through drought adaptive strategies: The case of Laikipia County, Kenya. Academic Research International 4(3),453-465.

Huho, J.M., Ngaira, J.K. W., Ogindo, H.O. \& Masayi, N., 2012. The changing rainfall pattern and the associated impacts on subsistence agriculture in Laikipia East District, Kenya. J. Geo. Regional Planning 5(7),198-206. http://doi.org/10.5897/JGRP12.018

Jackson, P.G.G. \& Cockcroft, P.D., 2002. Appendix 2: Laboratory reference values: Haematology. Blackwell Science Ltd. New Jersey, United States.

Jian, W., Duangjinda, M. \& Vajrabukka, C., 2013. Differences of skin morphology in Bos indicus, Bos taurus, and their crossbreds. Int. J. Biom. (Pan 1963). http://doi.org/10.1007/s00484-013-0700-9

Jian, W., Ke, Y. \& Cheng, L., 2015. Physiological responses and lactation to cutaneous evaporative heat loss in Bos indicus, Bos taurus, and their crossbreds. Asian-Austral. J. Anim. Sci. 28(11), 1558-1564.

King'uyu, S., Kilavi, M., Omeny, P., Muigai, E. \& Njogu, A., 2009. Climate change indices for Kenya. J. Meteor. Related Sci, 49-55. Accessed at http://www.kms.or.ke/phocadownload/vol 5 paper 6.pdf

Kucevic, D., Plavši, M., Trivunovi, S., Radinovi, M. \& Bogdanovi, V., 2013. Influence of microclimatic conditions on the daily production of dairy cows. Biotechnol. Anim. Husb. 29(1),45-51. http://doi.org/10.2298/BAH1301045K

Mazzullo, G., Rifici, C., Cammarata, F., Caccamo, G., Rizzo, M. \& Piccione, G., 2014. Effect of different environmental conditions on some haematological parameters in cow. Ann. Anim. Sci. 14(4), 947-954. http://doi.org/10.2478/aoas-2014-0049

McManus, C., Prescott, E., Paludo, G.R., Bianchini, E. \& Louvandini, E.H.M.A., 2009. Heat tolerance in naturalized Brazilian cattle. Livest. Sci. 120 (April 2016), 256-264. http://doi.org/10.1016/j.livsci.2008.07.014

Mcsweeney, C., New, M. \& Lizcano, G., 2010. UNDP Climate Change Country Profiles: Kenya.

Moran, J., 2012. Environmental management. In: Managing high grade dairy cows in the tropics (pp. 131-141). CSIRO Publishing, Melbourne, Australia.

Musari, A., Adewale, A. \& Olonade, K., 2014. Determination of heat stress in North-West Region of Nigeria. Res. J. Eng. Appl. Sci. 3(4), 232-238.

Musau, J., Sang, J., Gathenya, J. \& Luedeling, E., 2015. Hydrological responses to climate change in Mt. Elgon watersheds. J. Hydrol: Regional Studies 3,233-246. http://doi.org/10.1016/j.ejrh.2014.12.001

Ngeno, K., Omasaki, S.K. \& Bebe, B.O., 2014. Assessment of the vulnerability and adaptation strategies to climate variability of the Bos-taurus dairy genotypes in Nandi and Nakuru counties in Kenya. J. Anim. Prod. Adv. 3 (7),186-196.

Omondi, W. \& Njehia, B., 2014. Herd characteristics on smallholder dairy farms in Western Kenya. J. Anim. Sci. Adv. 4(8),996. http://doi.org/10.5455/jasa.20140827111904

Onasanya, G.O., Oke, F.O., Sanni, T.M. \& Muhammad, A.I., 2015. Parameters Influencing haematological,serum and bio-chemical references in livestock animals under different management systems. Open J. Vet. Med. 5 (August),181-189. Accessed at http://www.scirp.org/journal/ojvm http://dx.doi.org/10.4236/ojvm.2015.58025\%0AParameters

Ramirez-Villegas, J., Lau, C., Hooker, J., Jarvis, A., Ann-Kristin, K., Arnell, N. \& Tom, O., 2011. Climate analogues: Finding tomorrow's agriculture today. CGIAR Research Program on Climate Change, Agriculture and Food Security.

Rana, M.S., Hashem, M.A., Sakib, M.N. \& Kumar, A., 2014. Effect of heat stress on blood parameters in indigenous sheep. J. Banglad. Agric. Univ. 12(1),91-94.

Roland, L., Drillich, M. \& Iwersen, M., 2014a. Hematology as a diagnostic tool in bovine medicine. J. Vet. Diagn. Invest. 1(7). http://doi.org/10.1177/1040638714546490

Roland, L., Drillich, M. \& Iwersen, M., 2014b. Hematology as a diagnostic tool in bovine medicine. J. Vet. Diagn. Invest. 26(5),592-598. http://doi.org/10.1177/1040638714546490

Schoen, C., 2005. A new empirical model of the temperature-humidity index. J. Appl. Meteor. 44,1413-1420.

Suklerd, S., Katawatin, S., Duangjinda, M. \& Roytrakul, S., 2015. 763 Pattern of Hsp72 and Hsp73 expression, and physiological responses in the cattle with different thermo-tolerant capacity. Khon Kaen Agric. J. 43(4), 763-772.

USAID., 2010. a climate trend analysis of Kenya - August 2010 (Vol. 1975). Accessed at http://www.fews.net/docs/Publications/FEWS Kenya Climate Trend Analysis.pdf

Washington, R. \& Pearce, H., 2012. Climate Change in East African Agriculture: Recent trends,current projections,cropclimate suitability,and prospects for improved climate model information (February). Accessed at http://ccafs.cgiar.org/resources/tools-maps-models-and-data/testing-climate-models-agricultural-impacts 